\title{
Erratum: Super-resolution microscopy reveals that disruption of ciliary transition-zone architecture causes Joubert syndrome
}

\author{
Xiaoyu Shi, Galo Garcia III, Julie C. Van De Weghe, Ryan McGorty, Gregory J. Pazour, Dan Doherty, Bo Huang \\ and Jeremy F. Reiter
}

Nature Cell Biology http://dx.doi.org/10.1038/ncb3599 (2017); published online 28 August 2017;

corrected after print 25 September 2017.

In the original version of this Article, the name of author Galo Garcia III was coded wrongly, resulting in it being incorrect when exported to citation databases. This has now been corrected, though no visible changes will be apparent. 